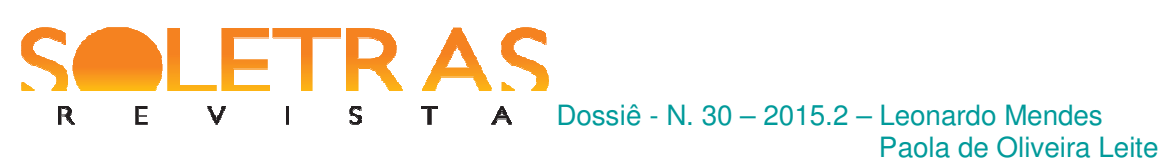

\title{
As trajetórias de Suicida! (1895) e O terror dos maridos (1896), romances naturalistas esquecidos de Figueiredo Pimentel
}

\author{
Leonardo Mendes ${ }^{1}$ \\ Universidade do estado do Rio de Janeiro \\ Paola de Oliveira Leite ${ }^{2}$
}

Graduanda em Letras pela Universidade do Estado do Rio de Janeiro

\begin{abstract}
Resumo: Esse artigo conta a história da publicação, circulação e recepção dos romances naturalistas esquecidos Suicida! (1895) e $O$ terror dos maridos (1896), de Alberto Figueiredo Pimentel (1869-1914), escritor brasileiro de atuação destacada nas cenas literária e jornalística do Rio de Janeiro nas décadas de 1890 a 1910. Como outros escritores da Primeira República, Figueiredo Pimentel foi um polígrafo que praticava vários gêneros de escrita: poesia, conto, novela, teatro, crônica, folhetim, romance e, destacadamente, a literatura infanto-juvenil, da qual ele foi um dos introdutores no Brasil. Em 1893, estreou no romance com a publicação do escandaloso $O$ aborto (1893), que foi um best-seller do fim de século. Para contar a história dos romances selecionados, utilizaremos como ferramenta de pesquisa os periódicos disponíveis no site da Hemeroteca Digital Brasileira/FBN.
\end{abstract}

Palavras-chave: Figueiredo Pimentel. Naturalismo. Literatura. Imprensa.

\section{Introdução}

A aparição do escritor Alberto Figueiredo Pimentel (1869-1914) na cena literária do Rio de Janeiro no início da década de 1890 foi explosiva. Na época, era quase impossível não se falar dele, pois parecia estar em todos os lugares ao mesmo tempo. Poemas de sua lavra saíam regularmente em impressos variados, em todas as regiões do país, onde tinham boa acolhida. Jornais e revistas efêmeros surgiam e desapareciam e o nome de Figueiredo Pimentel estava quase sempre lá, como redator ou colaborador. Escrevia sonetos parnasianos com melancolia decadentista, alguns reunidos e publicados em volume, como Livro mau

\footnotetext{
1 Professor Associado do Departamento de Letras da Faculdade de Formação de Professores e Professor Permanente do Programa de Pós-Graduação em Letras do Instituto de Letras da Universidade do Estado do Rio de Janeiro. É pesquisador do Grupo de Pesquisa ARS (Arte, Realidade, Sociedade) FBN/UFRJ/CNPq e do Grupo Internacional de Pesquisa "A circulação transatlântica dos impressos e a globalização da cultura no século XIX”, UNICAMP/FAPESP/CNPq. Autor de vários artigos em periódicos indexados na área. Seus interesses de pesquisa são a prosa de ficção brasileira de 1870 a 1920, o naturalismo literário no Brasil, na França e na Inglaterra, e a história do livro e da leitura.

${ }^{2}$ Graduanda em Letras (Português/Inglês) pela Universidade do Estado do Rio de Janeiro e bolsista PIBIC 20132015.
}

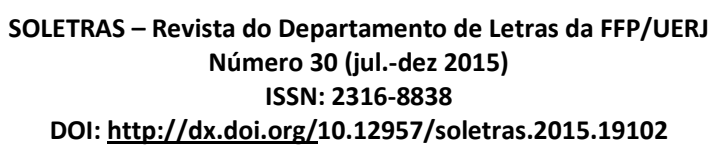


(1891) e Amor (1896), entre outros. Assinava colunas, folhetins e crônicas em periódicos nacionais e estrangeiros, com pseudônimos e com o próprio nome (VIEIRA, 2015). Estava presente nas conferências literárias mais badaladas, nas redações dos principais jornais, nos aniversários e enterros de escritores, quando proferia discursos. Trabalhava na tradução e adaptação de histórias para crianças, como o pioneiro e popular Contos da Carochinha, que em 1898 já estava na terceira edição. E finalmente, na faceta que nos interessa aqui, publicava romances naturalistas com títulos sensacionalistas, como $O$ aborto (1893), Um canalha (1895), Suicida (1895) e O terror dos maridos (1896) (MENDES, 2015).

Entre os contemporâneos, a capacidade de trabalho de Figueiredo Pimentel causava espanto. Perguntavam-se como era possível um escritor atuar ao mesmo tempo em tantas frentes e abraçar tantos gêneros, projetos e estilos. Chamavam-no de "laborioso" ou "operoso" escritor, pois mal havia publicado um livro, já anunciava ter mais dois ou três no prelo. Araripe Júnior (1848-1911) o descrevia como "um rapaz de talento que necessita [va] ser acossado com ferro em brasa, como se costuma [va] fazer às feras indomáveis" ( $A$ Semana, 21/04/1894, p. 299). Em 28 de janeiro de 1898, a Gazeta da Tarde computava em 27 o número de obras escritas por Figueiredo Pimentel, que tinha, então, 29 anos. Tal capacidade de trabalho, diziam os jornais, só era comparável à de Coelho Neto (1864-1934), outro prolífico escritor esquecido. A percepção de que Figueiredo Pimentel era uma "fera indomável" iria persistir até o final da década, quando ele abandonou o polêmico romance naturalista e assumiu o posicionamento mais confortável de autor de literatura infantil e juvenil (LEÃO, 2012), assim como de cronista do high life carioca na coluna "Binóculo", na influente Gazeta de Notícias, na primeira década do século (NEEDEL, 1987). Enquanto viveu, Figueiredo Pimentel foi um bem-sucedido escritor profissional, conhecido em todo o Brasil e mesmo fora dele.

Os quatro romances que escreveu entre 1893 e 1896 eram produtos de um jovem escritor em ascensão que usava o naturalismo para causar escândalo e testar os limites do que se podia ler e dizer sobre o corpo e o sexo. Figueiredo Pimentel se beneficiava de um momento de expansão do mercado editorial e do público leitor (EL FAR, 2004), assim como de um ambiente cultural de abertura ao "novo", numa sociedade que acabara de depor o imperador e declarar ilegal a escravidão. ${ }^{3}$ Ele não era um escritor naturalista tradicional, como

\footnotetext{
3 "Novo" era um título em disputa no campo literário brasileiro na primeira década republicana. Era reivindicado pelos "escritores menores", como os poetas simbolistas e decadentistas, mas também por prosadores naturalistas, como o catarinense Virgílio Várzea (1864-1943) e o cearense Adolfo Caminha (1867-1897). "Novo", portanto, SOLETRAS - Revista do Departamento de Letras da FFP/UERJ 
Émile Zola (1840-1902) ou Aluísio Azevedo (1857-1913), para quem o naturalismo era um posicionamento estético-político e única arte realmente legítima da civilização industrial do século XIX (BAGULEY, 1991). Nesse sentido, ele não era naturalista por vocação, mas um escritor profissional que escrevia, entre outras coisas, romances naturalistas. É claro que, em defesa dos livros, ele também reivindicava, como fizeram Émile Zola, Aluísio Azevedo, Júlio Ribeiro (1845-1890) e Adolfo Caminha, a seriedade do "escritor cientista", que observava, estudava e condenava (os males da sociedade), mas ao chamar seus romances de "naturalistas", Figueiredo Pimentel visava mais ao sensacionalismo do que ao cientificismo da estética.

Isso quer dizer que devemos ler seus romances naturalistas como obras escritas para chocar e vender, sem a densidade e a grandiosidade épica dos livros de Zola (ou mesmo de Aluísio Azevedo e Adolfo Caminha), mas seguramente "científicos" no sentido de que faziam uma narrativa fria que mostrava os fatos sem julgar. Os escritores naturalistas, é claro, julgavam - o aspecto "denuncista" do romance naturalista era uma forma de julgamento -, mas havia um esforço (em nome da neutralidade científica) para não julgar, que lhes permitia tratar de assuntos até então restritos à literatura libertina e clandestina. Por isso, na França e no Brasil, a percepção imediata do público era de que a ficção naturalista era pornográfica. Os escritores naturalistas rejeitavam essa percepção. Para eles, os romances que escreviam não eram livros para se arquivar em "museus secretos", como faziam com as obras libertinas e licenciosas publicadas até então (KENDRICK, 1987). A rejeição da clandestinidade era a novidade do discurso sobre o sexo engendrado pelo naturalismo. Na Europa e no Brasil, a publicização e a tentativa de banalização do sexo da ficção naturalista causaram muito atrito. Matriz da pornografia moderna, o romance libertino do século XVIII era caro e para poucos; não era discutido em público. Para os escritores naturalistas, ao contrário, o lugar da ficção que escreviam era a arena pública, vendida a preço módico e guardada ao lado de outras obras respeitáveis nas bibliotecas das casas burguesas.

A ideia de que o discurso naturalista sobre o sexo não era pornográfico - como acreditamos hoje - só seria aceita pelo grande público a partir da década de 1920 (KENDRICK, 1987). No primeiro momento de circulação, o argumento da seriedade do

não delimitava uma opção estética, mas uma posição dominada no campo. Figueiredo Pimentel foi considerado um dos "novos" quando surgiu, especialmente por sua poesia decadentista. Da mesma geração que Figueiredo Pimentel e Adolfo Caminha, Olavo Bilac (1865-1918) e Coelho Neto (1864-1934), que eram ligados aos escritores dominantes, não eram dos "novos". Porque foi derrotada, a batalha dos "novos" em 1890 escapou à historiografia.

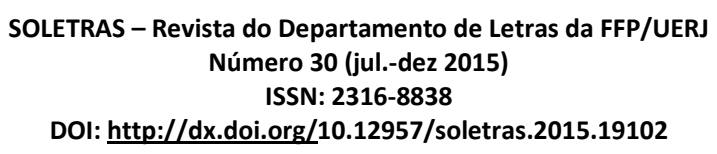




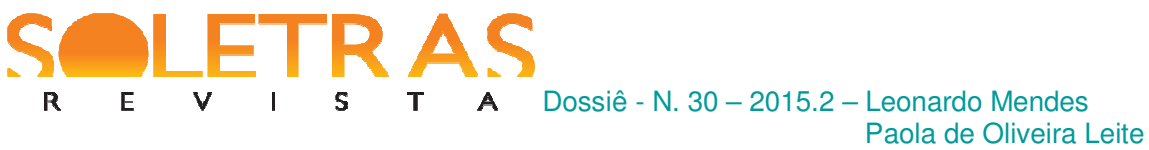

naturalismo só foi levado a sério pelos próprios escritores naturalistas e seus apoiadores. De modo geral, livreiros e leitores do segundo oitocentos acreditavam que o romance naturalista não passava de literatura pornográfica velada por uma intenção científica. Fora do círculo dos escritores naturalistas, outros homens de letras concordavam com essa opinião e repudiavam, por obscenos, romances naturalistas que o século XX canonizaria. No Brasil, dois pesos pesados do campo literário do final do século XIX, Artur Azevedo (1855-1908) e Valentim Magalhães (1859-1903), ambos com poder para alavancar ou enterrar carreiras, foram veementes no repúdio de Bom-Crioulo (1895), de Adolfo Caminha. ${ }^{4} \mathrm{O}$ duro posicionamento dos dois escritores, que admiravam a obra de Zola e o romance naturalista de Aluísio Azevedo e Eça de Queiróz, deixava claro que o problema não era o naturalismo em si, mas o naturalismo de certos escritores novos que queriam competir no espaço de mercado que eles dominavam.

A recepção duríssima de Artur Azevedo e Valentim Magalhães a Bom-Crioulo oferece paralelo ilustrativo para os romances naturalistas de Figueiredo Pimentel, que era, como Adolfo Caminha, um outsider (HOWES, 2005), embora compartilhasse espaços com outros artistas de maior pedigree. Artur e Magalhães pertenciam ao grupo dos escritores dominantes, com acesso às melhores livrarias e colunas de jornais, que fundaram a Academia Brasileira de Letras em 1897. Não por coincidência, Figueiredo Pimentel enfrentou a mesma força que fez desaparecer Bom-Crioulo por décadas. Tal era a influência do grupo ligado à ABL que, mesmo tendo sido um sucesso de livraria em 1895, o romance de Adolfo Caminha só seria reeditado na década de 1930. A mesma força fez sumir do mapa o romance de estreia de Figueiredo Pimentel, outro êxito comercial do período. Em 1893, a primeira edição de $O$ aborto vendeu incríveis seis mil exemplares (EL FAR, 2004), dos quais só conhecemos três. ${ }^{5}$ Em 1895, tendo à frente a poderosa dupla Artur e Magalhães, desta vez com a ajuda do igualmente influente José Verissimo (1857-1916), o ataque a Um canalha, segundo romance naturalista de Figueiredo Pimentel, mesmo que por outras razões que não a pornografia, reduziu o livro a pó (MENDES \& VIEIRA, 2014).

\footnotetext{
${ }^{4}$ Artur julgou o romance "um erro" e confessou que aquele "estudo grosseiro de pederastia" lhe dava náuseas $(O$ País, 05/01/1897, p. 1). Para Valentim Magalhães, Bom-Crioulo era "um livro podre". A obra que a historiografia contemporânea celebra como o primeiro romance de literatura gay made in Brazil (BEZERRA, 2007; FORSTER, 1991), Valentim Magalhães chamava de "o romance-vômito, o romance-poia, o romance pus". Ele ficou tão chocado com a audácia do livro, que o definiu como um novo subgênero de literatura pornográfica, voltada para o sexo entre homens (A Notícia, 20/11/1895, p. 1).

${ }^{5}$ Conhecemos o exemplar da Biblioteca Nacional do Rio de Janeiro, da Biblioteca José de Alencar da Faculdade de Letras da UFRJ, e da Biblioteca César Lattes da Unicamp. A segunda edição de $O$ aborto foi organizada por nós e Pedro Paulo Catharina e publicada em 2015 pela editora 7Letras, do Rio de Janeiro.
} 
Ao tomarmos como objeto de estudo o romance naturalista de Figueiredo Pimentel, devemos ter em mente tal ambiente hostil. Como escritor naturalista, ele nunca deixou de ser um iconoclasta ou uma "fera indomável", como queria Araripe Junior, com coragem para chocar o público e comprar briga com outros agentes do campo, mesmo os mais influentes. Até seus admiradores reconheciam que, às vezes, ele "se desequilibra[va] e arroja[va] ao mundo um desses livros que põem legiões de espantos nos esconderijos dos nossos cérebros" (Revista do Brasil, dez. 1897). Em março de 1896, quando correu a notícia de que Figueiredo Pimentel publicaria um novo "panfleto semanal" de arte literária chamado "FIAU...!FIAU...!", um articulista do jornal Cidade do Rio notou "que o escândalo ser[ia] a principal nota da nova publicação; também quase podemos garantir-lhe o sucesso" (Cidade do Rio, 06/03/1896, p. 2). Mas o escândalo era um risco e o sucesso não impressionava os escritores dominantes. A julgar pelas fontes, entretanto, os quatro romances naturalistas de Figueiredo Pimentel foram empreendimentos editorais bem-sucedidos - vale dizer, são documentos importantes da história do livro e da leitura no Brasil.

Para conhecer as trajetórias de publicação e recepção dos romances Suicida! e $O$ terror dos maridos, vamos usar os exemplares disponíveis na Biblioteca Nacional do Rio de Janeiro, que foram fotografados e lidos, assim como a Hemeroteca Digital Brasileira, da mesma instituição, de onde recolhemos anúncios de livrarias, notas, comentários, resenhas e ilustrações relacionadas aos dois livros esquecidos e à trajetória de Figueiredo Pimentel como autor de romances naturalistas. Esse material foi por nós levantado, selecionado e organizado para apresentação nesse artigo.

\section{Suicida!}

Embora negasse em prefácios e comentários na imprensa, Figueiredo Pimentel encarava a literatura como um empreendimento comercial. Tinha preferência por títulos sensacionalistas (até para livros de poesia) e usava seu trânsito na imprensa para atrair a atenção dos leitores e alavancar a venda de livros. Suicida! (com sinal de exclamação, como um grito e/ou uma acusação) foi o projeto editorial naturalista mais bem-sucedido do escritor. Ele foi planejado e executado com rapidez e eficiência entre abril e outubro de 1895 , e teve boa acolhida de crítica e público. Primeiro, Figueiredo Pimentel criou um factoide: forjou o próprio suicídio. Morador de Niterói, abandonou no dia 25 de abril sua capa, chapéu e carteira na barca de retorno à cidade, além de uma carta justificando o ato. Na carta, lia-se:

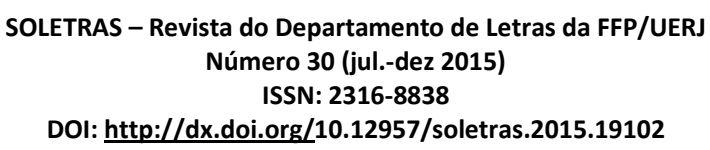


O homem tem por missão principal procriar. Todo o seu fim é a propagação da espécie. Ora, não terá o direito, o dever de eliminar-se aquele que não puder cumpri-lo? Um sofrimento físico, uma deformidade, uma amputação destituem o homem das suas coesões. Que tem ele a fazer neste caso? Suicidar-se. Uma enfermidade incurável, que conduz fatalmente, inevitavelmente à morte apossa-se de um indivíduo. Os seus filhos serão raquíticos, escrofulosos, sifilíticos. Para evitar esses males, só existe o suicídio. A justiça, a lei, arrogaram-se o direito iníquo e bárbaro de dispor da vida de um homem, um criminoso. Então, quem se julga um criminoso perante sua própria consciência, não pode, com mais razão, dispor da sua vida? O homem é o único animal que se suicida. O suicídio é um direito e muitas vezes um dever. O suicídio é um direito como qualquer outro, tão legítimo como o direito da defesa própria. Para certos casos, só ele existe como recurso extremo embora, mas inevitável (Correio Paulistano, 29/04/1895, p. 2).

O gesto e a carta eram formas de colocar seu nome nas páginas dos jornais, mas também de defender a tese de que, em determinadas circunstâncias, era legítimo pôr fim à própria vida, como seria argumentado no romance em seguida. A carta trazia marcas do imaginário naturalista-decadentista do final do século XIX, na concepção biológica do homem como organismo descartável quando tem defeito, assim como nas fantasias de degenerescência e ruína associadas à experiência e ao corpo humanos (PICK, 1989). Caro à ficção naturalista, o tema da hereditariedade - que rejeitava a autonomia do homem na construção do seu destino - era central na carta (e no romance). Figueiredo Pimentel falava como um homem doente e defeituoso que havia escolhido pôr fim à própria vida. Do ponto de vista da natureza - que era o ponto de vista do escritor naturalista -, sua doença era um crime de lesa-natureza. Que se outorgasse a esse "criminoso" o direito (ou ainda o dever) de se defender de si próprio e da herança de seu sangue ruim, pondo fim à própria vida.

Como era de se esperar, o suicídio de Figueiredo Pimentel causou grande comoção naquele final de abril. O Correio Paulistano comentou a "triste notícia" e julgou a decisão do escritor um "ato de loucura" inexplicável (29/04/1895, p. 1). Figueiredo Pimentel se escondeu num sítio nos arredores de Magé, no interior do estado, enquanto os jornais lamentavam sua morte e a polícia procurava o cadáver (GRIECO, 1933). O suicídio do escritor era um evento perturbador, chocante e violento. A defesa do ato na carta tornava o episódio ainda mais misterioso e arrepiante. O suicídio era outro tema tabu - como o aborto - que ele tinha a audácia de trazer para a literatura pelo naturalismo. O mistério só terminou quando o escritor Medeiros e Albuquerque (1867-1934) foi a Niterói levar os pêsames à família em nome dos homens de letras da capital, alguns dias depois. A essas alturas Figueiredo Pimentel já 
retornara à própria casa e foi surpreendido na sala de jantar, vivo, "comendo doce de jaca" (EDMUNDO, 1938, p. 684).

Desfeita a farsa, Figueiredo Pimentel assumiu, num artigo de 2 de maio, no jornal $A$ Notícia, que seu gesto visava criar um ambiente de interesse pelo suicídio, com vistas à publicação de um romance sobre o assunto no folhetim daquele jornal, a partir daquele dia. Em carta para Artur Azevedo, o escritor explicou que acreditava no direito de pôr fim à própria vida, mas que, essencialmente, queria fazer reclame de seu nome romance, intitulado Suicida! (O País, 03/05/1895, p. 2). A crer no articulista Pinto, na coluna "Pequenos Ecos" da Revista Ilustrada, a tática do escritor foi bem-sucedida:

Grande júbilo tivemos em abraçar o Figueiredo Pimentel, depois das notícias alarmantes, que por aí correram, sobre seu suicídio. E pegando na Notícia, como de costume, aí deparamos com o seu sensacional artigo sobre o fato, e daí para cá nem um só dia deixamos de ler o seu romance Suicida, que ali está publicando. Caímos como uns patinhos, e agora é todo dia esperando a continuação do seu novo romance. Danadinho... (Revista Ilustrada, n. 684, 1895, p. 3).

O romance foi publicado no rodapé do jornal A Notícia em maio e junho de $1895 .^{6}$ Naqueles meses, "as edições se esgotaram todos os dias" (Almanaque Literário e Estatístico do Rio Grande do Sul, 1902, p. 31). O sucesso do folhetim pode ser confirmado por uma ilustração do caricaturista Julião Machado, que em parceria com Olavo Bilac lançava, naqueles dias, a revista A Cigarra. No primeiro número, de 9 de maio de 1895, numa ilustração que era uma propaganda da própria revista, um casal burguês lia na cama numa manhã de domingo. A propaganda sugeria um casal com tédio sexual. "Quando o hábito já esfriou os primeiros transportes", ela lia a revista A Cigarra para fugir ao tédio das manhãs de domingo, enquanto ele lia o jornal A Notícia, com destaque para o romance Suicida! na primeira página.

\footnotetext{
${ }^{6}$ A Hemeroteca Digital Brasileira não possui exemplares de A Notícia referentes ao primeiro semestre de 1895 , de modo que a pesquisa não localizou o artigo de Figueiredo Pimentel, nem o texto original do folhetim. 
$\begin{array}{lllllll}\text { R } & \text { E } & \text { V } & \text { I } & \text { S } & \text { T } & \text { A Dossiê - N. } 30-2015.2-\text { Leonardo Mendes }\end{array}$

Paola de Oliveira Leite

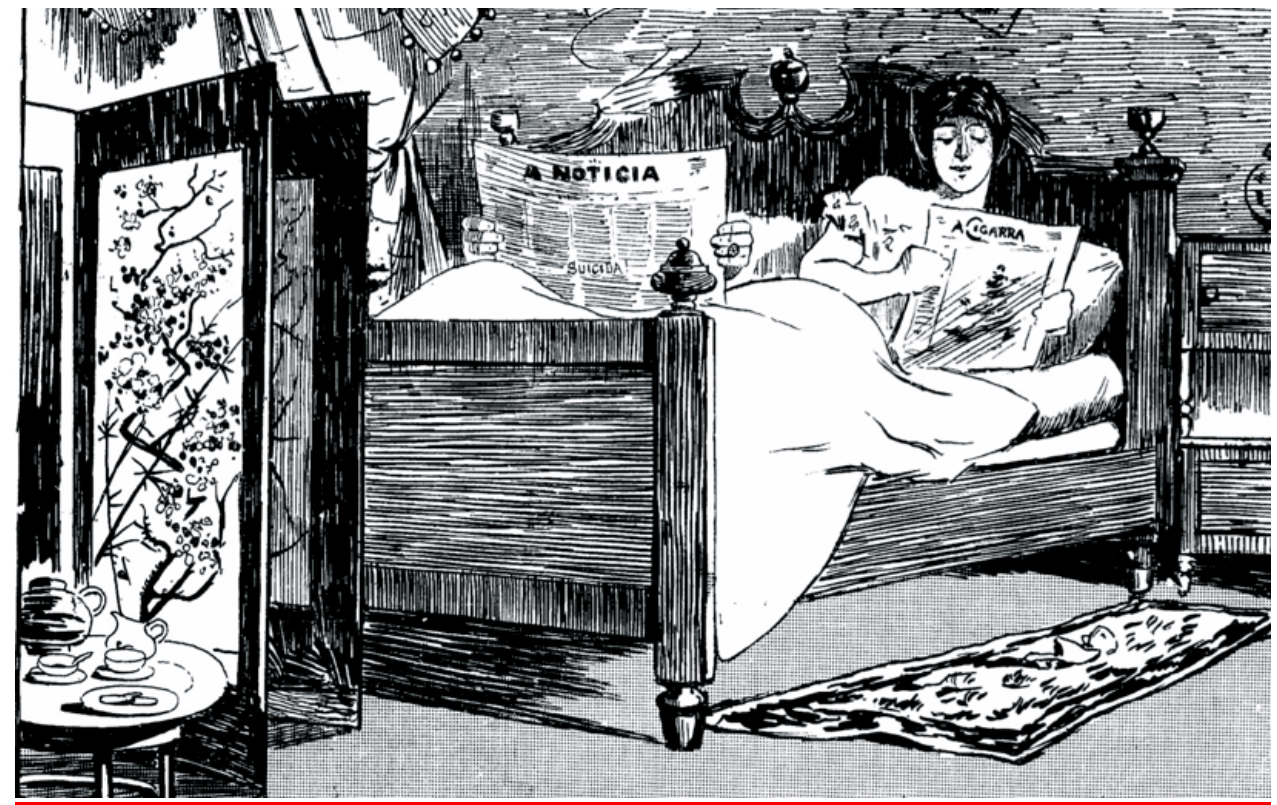

Fig. 1: Detalhe da ilustração "Domingo de inverno", por Julião Machado.

Fonte: A Cigarra, n. 1, 09/05/1895, p. 4.

Em outubro de 1895, o folhetim saiu em formato de livro pela Casa Fauchon, do Rio, numa edição de luxo com capa a quatro cores, ao preço acessível de 3 mil réis (A Notícia, 25/10/1895, p. 2). O livro podia ser comprado em livrarias da capital, Maranhão, Recife, Vitória, Florianópolis e Porto Alegre, às vezes, com desconto, a 2 mil e 500 réis. Os anúncios da publicação do livro remetiam à sensação de que o folhetim havia causado no "público ledor" (A Notícia, 23/10/895, p. 4), assim como à "escandalosa e originalíssima reclame" do autor (O País, 23/08/1895, p. 2). Julião Machado era o ilustrador da capa do livro, sugerindo que Suicida! era um empreendimento artístico e comercial que reunia vários agentes do campo: dono de jornal, escritor, livreiro e ilustrador.

O romance é narrado em primeira pessoa e conta a história de Domingos Pacheco, herdeiro de uma poderosa família de fazendeiros escravistas da província do Rio de Janeiro, os Alves Pacheco, nos anos de crise do sistema monárquico. A família era proprietária de várias fazendas de café no entorno de Macaé, cidade natal de Figueiredo Pimentel, a 150 km da Corte. Domingos Pacheco nasceu e foi criado na fazenda Barro Vermelho, do seu avô Domingos Alves Pacheco, coronel da Guarda Nacional. A um dia de caminhada estava a fazenda Pindobas, de seu bisavô, Comendador João Pedro Alves Pacheco, filho de um fidalgo português que viera para o Brasil com D. João VI em 1808. O narrador, de vinte e poucos anos, decide escrever um relato de sua vida para contextualizar e explicar sua decisão de se 


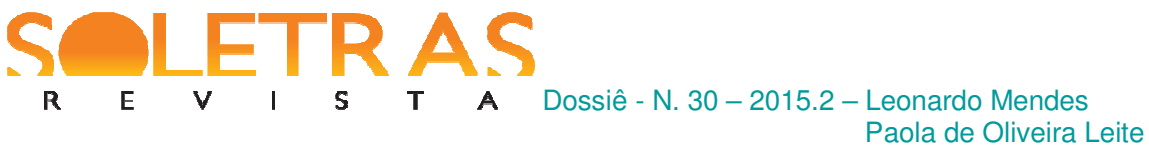

matar ao término da narrativa. Nesse sentido, a narrativa era uma carta de despedida que terminava com a morte do autor.

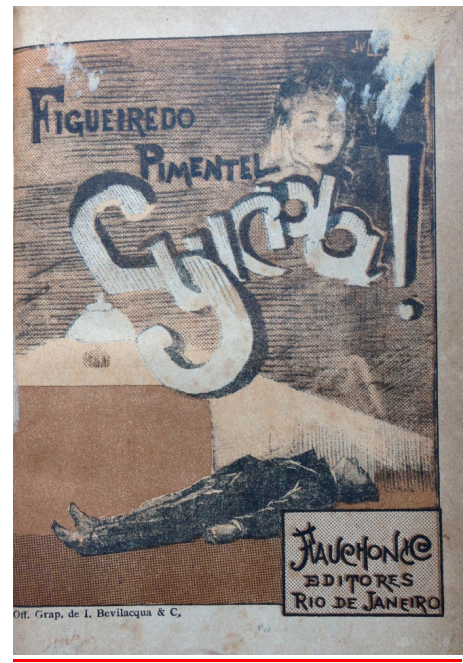

Fig. 2: Capa de Suicida!, por Julião Machado.

Fonte: Exemplar da Biblioteca Nacional do Rio de Janeiro.

Para assegurar o controle sobre a propriedade, os membros da família Alves Pacheco eram obrigados a se relacionar e procriar entre si. Como não havia nenhum parente disponível para se casar com sua filha Lauriana, o coronel Pacheco obrigou-a ao celibato forçado até muito tarde, levando-a a ter ataques histéricos e exibir os primeiros sinais de loucura. Numa configuração naturalista típica - que vemos, por exemplo, em $O$ homem (1887), de Aluísio Azevedo -, o médico prescreve o casamento para a moça infeliz como profilaxia da histeria. Por fim, o coronel encontra um marido para a filha, seu irmão mais novo, que recentemente enviuvara e que concordara em se casar com a sobrinha para que ela não passasse o infortúnio de morrer virgem e solteira. Tanto o celibato forçado quanto o sexo intrafamiliar explicariam a loucura de Lauriana, que perdeu o primeiro filho, mas teve um segundo, o narrador, sempre muito magro e adoentado.

Domingos Pacheco escreve como herdeiro da classe senhorial escravista brasileira. Fala da violência que cercava sua infância como se fosse algo corriqueiro. Lendas sobre assassinatos e emboscadas nas encruzilhadas eram narradas pelo avô. Nas madrugadas frias de inverno, os escravos, tiritando de frio, caminhavam para a lavoura. Cada fazenda tinha mais de 200. O pai foi assassinado a tiros quando Domingos ainda era criança, provavelmente por escravos da propriedade. Bá, uma das escravas que acabara de dar à luz a um menino, foi sua ama de leite, mas ela o maltratava, negando-lhe o peito, dando-lhe beliscões e arranhões. Sem pestanejar, o coronel Pacheco mandava castigar Bá todas as vezes que o menino chorava. Quando tinha quatro anos, depois de ferir a testa numa queda casual, Bá foi amarrada ao 


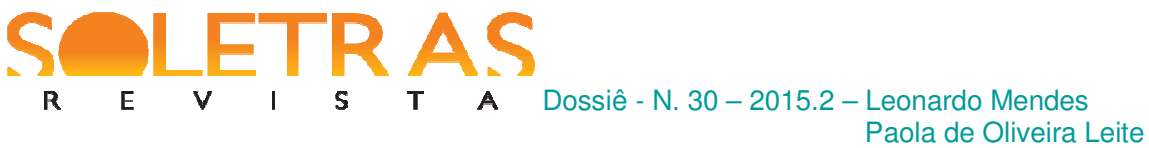

pelourinho e surrada pelo feitor com um dos instrumentos de tortura da fazenda escravista: o "bacalhau". Testemunha do açoitamento, Domingos sentiu um misto de satisfação e medo:

Foi depois do jantar, quase às quatro horas da tarde. Havia sombra no terreiro aos fundos a velha casa assobradada. Ligaram ao pau a rapariga, nua da cintura pra cima, mostrando as costas, em cuja pele fula se viam sinais de sevícias e cicatrizes fundas, algumas antigas, mais recentes outras.

Sentado à soleira da porta, muito encolhido, com os pesinhos pousados sobre um dos degraus de pedra que davam acesso à sala de jantar avarandada, eu apreciava satisfeito aquela cena, embora algum tanto amedrontado, e tremendo, quando eram mais fortes os gritos lancinantes e agoniados da vítima.

Com os olhos cravados no perfil sinistro, barbudo do feitor, acompanhava o movimento do bacalhau de três pernas, que rabeavam no ar, serpenteando em voltas caprichosas, caindo após, sibilantes, nas carnes de Bá, retalhandoas, fazendo grossos vincos esbranquiçados, que se purpureavam de pronto; e de novo erguendo-se, para outra vez caírem-se.

Depois escutei um grande grito - urro formidável de fera - e vi a escrava estortegar, esforçar-se para rebentar as cordas que a manietavam, tornandose em seguida quieta, imóvel (PIMENTEL, 1895, p. 22-23).

Quando Domingos fez seis anos, o coronel Pacheco lhe deu de presente Gilberto, filho de Bá. Aos 11 anos foi estudar no Colégio Fonseca em Macaé, quando descobriu que a louca da casa era sua mãe, que acabara de morrer. Desde então ficou triste e taciturno. Passou a colecionar opiniões amargas sobre as coisas e a descrer do futuro, perseguido pelo fantasma da herança do mau sangue da mãe. Aos 18 anos, mudou-se com o avô para o Rio de Janeiro, entrou para a Faculdade de Medicina, mas logo trocou os estudos pela vida boêmia. Passou a frequentar prostíbulos, casas de jogo e a beber todas as noites, por meses a fio, surpreso de que, condenado pela natureza, não lhe tivesse ainda acontecido nada. $\mathrm{O}$ argumento naturalista da hereditariedade explicava que na família Alves Pacheco "abundavam casos de degenerescência, com vícios e defeitos de alianças consanguíneas, manifestando-se na terceira geração, a que [ele] pertencia” (PIMENTEL, 1895, p. 124). Numa noite, no cabaré Maison Moderne, teve o primeiro ataque violento, seguido de desmaio. No dia seguinte, descobriu que estava paralisado do lado esquerdo do corpo. Ainda se mudaram para Petrópolis em busca de ares melhores, mas ao se descobrir sexualmente impotente, Domingos opta pelo suicídio:

É quase meia-noite - a hora que marquei... Está tudo preparado... Os ponteiros avançam rapidamente... A minha mão não treme... Confio em $\operatorname{mim} .$.

Meia-noite...

FIM (PIMENTEL, 1895, p. 155).

Suicida! foi o romance naturalista de Figueiredo Pimentel mais bem recebido pela imprensa e pelos homens de letras. A pesquisa não localizou nenhuma resenha sobre ele. $\mathrm{O}$ 
que há são notas e breves comentários sobre "o belo romance de Figueiredo Pimentel”, "o interessante romance de Figueiredo Pimentel” (A Notícia, 23/08/1895, p. 1), ou ainda, destacando a intenção científica, "romance naturalista e estudo profundo de uma singular situação fisiológica" (Almanaque Literário e Estatístico do Rio Grande do Sul, 1902, p. 31). A falta de resenhas, no caso do escritor, sinalizava para a boa acolhida de Suicida!. Talvez Figueiredo Pimentel não fosse bem-relacionado o bastante para receber elogios pelo livro, mas não o atacar era sinal de acolhimento. Um comentário numa resenha negativa a seu Livro mau, do articulista A. de F., da coluna "Crônica dos Livros" do jornal Cidade do Rio, talvez resumisse o que pensavam outros homens de letras: "quando será que Figueiredo Pimentel quererá quebrar a pena de $O$ aborto e deste mau livro e só escrever com a que produziu Suicida!?" (Cidade do Rio, 14/10/1895, p. 2).

\section{O terror dos maridos}

Em novembro de 1894, o jornal O Cachoeirano, de Cachoeiro de Itapemirim (ES), publicou em nota que Figueiredo Pimentel, "autor de $O$ aborto", tinha no prelo um novo livro chamado Os escândalos de Botafogo (O Cachoeirano, 11/11/1894, p. 3). À época da publicação do livro, três anos depois, ele mudaria o título para $O$ terror dos maridos, mas tanto o nome original quanto a data de sua concepção aproximam o último romance naturalista de Figueiredo Pimentel do primeiro, $O$ aborto. Mais do que Um canalha e Suicida!, $O$ aborto e $O$ terror dos maridos (ou Os escândalos de Botafogo) tinham títulos atrevidos, frontalmente antipatriarcais. O título original do último romance lembrava os populares folhetins de Eugène Sue (1804-1857), como Os mistérios de Paris (1842) (MEYER, 1996), com o apelo sensacionalista e a delimitação de Botafogo, bairro das pessoas de dinheiro, como espaço da narrativa. Tanto $O$ aborto quanto $O$ terror dos maridos eram romances naturalistas de estudo e denúncia dos hábitos sexuais inconfessáveis e da hipocrisia da burguesia e da pequena burguesia urbanas. Para não deixar dúvidas quanto ao alvo que mirava, ao mudar o título original, o escritor acrescentou o subtítulo "cenas da alta sociedade".

Como era de seu feitio, começou a aguçar a curiosidade do público com a publicação de anúncios e chamadas em vários jornais, avisando da chegada iminente de "o terror dos maridos" à cidade. A estratégia de divulgação pelo mistério e suspense havia sido usada com sucesso por Aluísio Azevedo na publicidade de seu romance-folhetim Filomena Borges 
(1884), quando contou com a ajuda de escritores do quilate de Machado de Assis (1839-1908) e de seu irmão Artur para plantar em vários jornais informações e pistas falsas sobre uma mulher misteriosa do mesmo nome que acabara de chegar ao Rio (LAMONICA, 2015). No caso do romance de Figueiredo Pimentel, a publicação do anúncio, que ocorreu por vários meses, criava um ambiente de terror e apreensão para as famílias, e especialmente para os patriarcas. Houve tanta especulação sobre o que aquilo significava, que em agosto de 1895 o jornal A Notícia veio a público esclarecer que não sabia quem (ou o quê) era "o terror dos maridos":

Esta pergunta tem nos sido feita milhares de vezes, verbalmente e por cartas desta capital e de fora, a propósito de um anúncio misterioso que já há dias estamos a publicar. Nada podemos adiantar, por enquanto, pago no balcão o aludido reclame, nem sabemos quem o trouxe e muito menos o que significa (A Notícia, 19/08/1895, p. 1).

\section{AVISOS}

Dr. Niennov Nascimento, a igado. - Rua do Rosario n. 57.

\section{(i) teroor dos maridos cis sra bravemente a esta cidade.}

Fig. 3: O terror dos maridos chegará brevemente a esta cidade. Fonte: Diário de Notícias, 04/09/1895, p. 1.

O mistério só foi desfeito em julho do ano seguinte, quando uma nota do jornal Cidade do Rio revelou a estratégia. Ao explicar que tudo não passava de um reclame de uma obra de Figueiredo Pimentel a ser lançada, o redator (que talvez fosse o próprio) prometia escândalo "cem vezes superior" a $O$ aborto, fazendo o vínculo com o explosivo (e bem-sucedido) romance de estreia. Ao mesmo tempo reivindicava a seriedade do documentalismo naturalista, a "observação e o estudo" da "sociedade elegante", o que era novidade, já que tanto Aluísio Azevedo quanto Adolfo Caminha (e até mesmo Zola) preferiam retratar os subalternos:

Há meses passados, durante muito tempo, em nossa folha, como em vários outros jornais desta capital, apareceu um anúncio misterioso, comunicando que $O$ terror dos maridos brevemente chegará a esta cidade. Ninguém sabia do que se tratava, nem podia explicar o caso. O anúncio devia ser uma simples mofina, tornando viva a referida cena de adultério, uma das numerosas que diariamente ocorrem no seio de todas as sociedades. 
Mas a coisa era outra. Tratava-se simplesmente de reclame a um romance de Figueiredo Pimentel que editado pela Livraria do Povo dos Srs. Quaresma \& C. será publicado dentro de breves dias. $O$ terror dos maridos promete ser um escândalo colossal, cem vezes superior ao Livro mau e a $O$ Aborto do mesmo autor.

Escrito com o estilo desembaraçado que usa Figueiredo Pimentel, é, entretanto um romance de observação onde o autor estuda a sociedade elegante do Rio de Janeiro, mostrando o que é a vida burguesa na rua, no lar, nas soirées, nos teatros em todas as superfícies, em suma. O livro é ansiosamente esperado (Cidade do Rio, 17 /06/1896, p. 1).

Esclarecido o caso, os jornais começaram a publicar notas sobre o aparecimento iminente do romance. $O$ País noticiou que a Livraria do Povo preparava para "os amadores do realismo" a edição de um novo romance de Figueiredo Pimentel, O terror dos maridos, da "mesma escola a que pertence $O$ aborto" ( $O$ País, 16/07/1896, p. 1). Mais expansiva, a Gazeta de Notícias anunciava "para breve mais um escândalo literário" com o aparecimento de $O$ terror dos maridos, "romance naturalista de Figueiredo Pimentel, o autor de $O$ aborto, Um canalha, Livro Mau e outras obras que o público conhece". O redator resume o enredo como uma "crônica escandalosa da alta sociedade do Rio de Janeiro, dos mistérios de Botafogo e Laranjeiras". A expectativa era de que o livro causasse polêmica e alcançasse sucesso, "principalmente por sua linguagem sem peias nem perífrases". Acrescentava que o romance era precedido de um prefácio em que Figueiredo Pimentel defendia-se "da pecha de imoral e pornográfico que lhe deitaram" (Gazeta de Notícias, 16/07/1896, p. 1). Era um ótimo reclame, pois, a negar a pornografia de sua obra, Figueiredo Pimentel só fazia chamar a atenção para ela. Na escandalosa dedicatória de $O$ aborto, três anos antes, o escritor dissera que aceitava (até com certo orgulho) a pecha de pornográfico (PIMENTEL, 2015, p. 21).

Embora as chamadas prometessem a publicação do romance pela Livraria do Povo, editora de $O$ aborto, $O$ terror dos maridos foi publicado por Jacinto Ribeiro dos Santos, da Livraria Cruz Coutinho, que explorava uma faixa similar do mercado livreiro, voltado para o livro popular (EL FAR, 2004). O romance só chegou às prateleiras em abril de 1897 e podia ser encontrado em livrarias de todo o Brasil. No dia 19, a livraria anunciava num reclame no Cidade do Rio que vendera 200 exemplares em quatro dias - um começo auspicioso. No final do mês, o Correio de Minas, de Juiz de Fora, confirmou que O terror dos maridos, "novo romance naturalista de Figueiredo Pimentel", fazia sucesso no Rio (Correio de Minas, 28/04/1897, p. 1). Os anúncios da livraria investiam francamente na reputação obscena do escritor, remetendo ao explosivo $O$ aborto. $O$ terror dos maridos trazia "cenas ao vivo passadas na alta sociedade fluminense de Botafogo e Laranjeiras, onde se desnuda [vam] as 
misérias, os namoros, os adultérios, mancebias e toda a prostituição do high-life do Rio de Janeiro". O anúncio chamava a atenção para o soneto (incompleto) de Artur Azevedo que o livro trazia como epígrafe, como prova de sua qualidade e garantia de sucesso (Cidade do Rio, 19/04/1897, p. 3):

Só entre o Botafogo e as Laranjeiras

Três damas há por ele apaixonadas,

Que, nas suas alcovas perfumadas

Lhe têm dado de amor noites inteiras!

Fatigado, afinal, de tanta peta,

E invejado por cínicos devassos,

De tais calúnias cada qual trombeta.

Venérea sede vai matar, nos braços

De uma infeliz mulher, barata e preta,

Lá para a rua do Senhor dos Passos.

O poema falava de um homem que tinha fama de conquistador entre as damas da alta sociedade carioca, mas era lorota (peta), pois só conhecia mulheres do baixo meretrício da cidade. No prefácio, ao admitir que se inspirara num conto irônico de Valentim Magalhães sobre "a vida extramarital" das damas cariocas, chamado "O irresistível" (MAGALHÃES, 1895, p. 41), Figueiredo Pimentel confirmava que se tratava da história de um falso sedutor, como sugeria o poema de Artur. De fato, Paulo Gurgel, o protagonista, um tímido professor e jornalista de Alagoas, era incapaz de consumar o ato sexual. O romance (ou novela, a como o próprio autor se refere à obra no prefácio) contava sua infância solitária em Maceió nos últimos anos do Império. A primeira experiência sexual com uma escrava causou-lhe péssima impressão. Tornou-se um jovem bonito que atraía as mulheres, mas era envergonhado e calado, "de gênio concentrado e taciturno" (PIMENTEL, 1896, p. 29). Não sabia como se aproximar das mulheres; não sabia o que dizer nem o que fazer. Simpático ao livro, um resenhista da Gazeta de Petrópolis arriscou que Paulo Gurgel era “misógino” (27/06/1897, p. 1). O narrador sugere que ele se encontrava com prostitutas, mas o romance era sobre o sexo que não acontecia. 


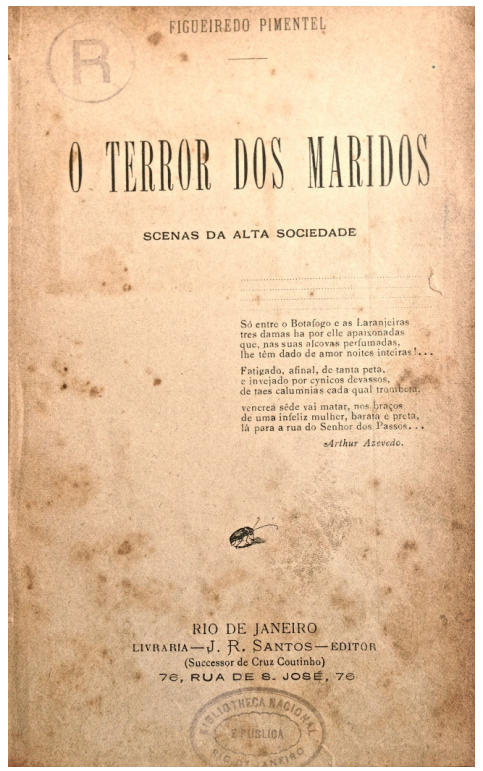

Fig. 4: Folha de rosto de $O$ terror dos maridos.

Fonte: Exemplar da Biblioteca Nacional do Rio de Janeiro.

Com a proclamação da República, Paulo Gurgel se dirige para o Rio de Janeiro em busca de uma nova vida, num novo Brasil. Tinha contatos na capital que lhe garantiam teto e comida, mas permaneceu desempregado durante meses, até a chegada de um senador alagoano de suas relações que lhe arrumou uma colocação numa secretaria de governo. $\mathrm{O}$ tédio dos meses de desemprego e o vazio do emprego público de fachada acrescentavam ao sentido de irrealização do romance. Foi o senador conterrâneo que o introduziu no circuito das festas luxuosas dos palacetes de Botafogo e Laranjeiras. Por esse acesso privilegiado, começou a correr a lenda nas rodas boêmias de que ele dormia com várias damas do high-life carioca. Transformara-se no irresistível terror dos maridos:

A sua fama de conquistador chegara ao auge. Espalhara-se por todo o Rio de Janeiro. Assumira as proporções fantásticas de uma legenda. Na opinião geral ela era um terrível D. Juan. Seduzia a torto e a direito mulheres casadas e meninas virgens, prostitutas e senhoras até então irrepreensivelmente honestas. Amas e criadas, mães e filhas, mulheres de todas as posições sociais, de todas as raças, de todas as cores, abriam-lhe os braços. Nenhuma só lhe resistia. Apelidaram-no o terror dos maridos (PIMENTEL, 1896, p. 184).

Era "peta", mas Paulo Gurgel compreensivelmente alimentava a lenda. Todos acreditavam porque:

Aquilo era natural, vulgar, corriqueiro mesmo, com a desmoralização que reinava na alta sociedade fluminense, com as suas semivirgens e mulheres casadas prostituídas. Naquela aristocracia fictícia de parvenus, o adultério era tão chique, tão simples, tão comum como usar uma flor ou assinar o Lírico (PIMENTEL, 1896, p. 176). 
Paulo Gurgel tentou viver à altura da fama, mas não conseguiu. O corpo paralisava sempre que uma mulher casada se oferecia a ele. Depois de tentar de tudo, a belíssima Madame Doëllinger não pôde se conter e lhe devolveu: "Burro!” (PIMENTEL, 1896, p. 157). $\mathrm{Na}$ cena final, depois de fracassar outra vez, pronto para explodir de frustração e desejo reprimido, Paulo Gurgel se masturba na rua, ao lado do muro do palacete em Laranjeiras onde outra dama lhe abrira inutilmente os braços.

Já no início de abril, o conservador Jornal do Comércio fez a primeira resenha condenatória. Tal era a desaprovação ao livro e ao autor, que o articulista se recusava a escrever o nome do romance, como ocorrera na época de publicação de $O$ aborto, quando Coelho Neto intitulou sua resenha de "O AB... (por Figueiredo Pimentel)" ( $O$ País, 26/03/1893, p. 1): "Figueiredo Pimentel publicou mais um livro de sua lavra. Não lhe mencionamos o nome, porque é livro que não pode ser anunciado ao público, e porque o público compõe-se de pessoas a quem não podemos aconselhar ou sequer indicar tal leitura". O escritor não podia contar com melhor propaganda. Como notou Valentim Magalhães no dia seguinte: "Que melhor anúncio de um livro do que a declaração de não o poder anunciar?" ( $A$ Notícia, 08/04/1897, p. 1). De fato, alguns meses depois, o comentário negativo do Jornal do Comércio foi audaciosamente reproduzido num anúncio da Livraria Cruz Coutinho como prova do valor e interesse da obra. A Livraria seguia ironicamente o conselho do jornal e optava por omitir o título do romance, substituindo-o pelo original Os escândalos de Botafogo, o que dava no mesmo. Gabava-se de em três meses ter vendido impressionantes 15 mil exemplares do livro (Gazeta de Notícias, 11/06/1897, p. 3).

Mesmo tendo um impostor como protagonista, $O$ terror dos maridos incomodava os moradores dos palacetes de Botafogo, como deixou claro o Jornal do Comércio, principal porta-voz das classes proprietárias. Mas o romance também tratava de espetar a imprensa e os homens de letras, num prefácio raivoso em que Figueiredo Pimentel fazia uma análise impiedosa do campo. Dizia que esperava uma avalanche de críticas ao livro porque desde $O$ aborto passara "aos olhos do público como escritor pornográfico". Lembrou o alvoroço que o livro de estreia causara e o sucesso de vendas: "milheiros e milheiros de exemplares se esgotaram em curto espaço de tempo". Para reafirmar a tese naturalista de que arte e moral nada tinham em comum, citou o prefácio de Mademoiselle de Maupin (1835), de Théophile Gautier (1811-1872). Lamentou a persistência de sua "má fama", mesmo depois da publicação de Um canalha, Suicida! e Histórias da Carochinha, que nada tinham de pornográficos. Alegando falar com conhecimento de causa, pois desde 1883 militava no meio, 


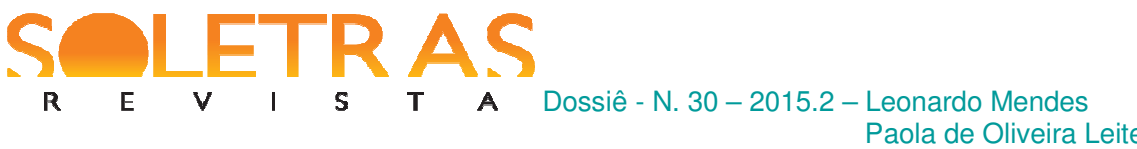

atacou a imprensa. A opinião dos jornalistas, acusou, apenas reproduzia o pensamento dos proprietários das folhas, que se limitavam a acusar o recebimento das obras de novos autores, sem nunca resenhá-las; os redatores eram "beócios" que optaram pelo jornalismo por incapacidade de bacharelar-se; artigos laudatórios eram comprados "a tanto por linha". Por isso sabia que seria outra vez "mordido pelos hidrófobos do jornalismo fluminense" (PIMENTEL, 1896, p. 19).

Apesar de homenageados como autores da epígrafe e do conto inspirador, Artur Azevedo e Valentim Magalhães não gostaram do prefácio. Ocupando trechos da sua prestigiosa coluna "Palestra" no jornal $O$ País, Artur negou que as opiniões de jornalistas pudessem ser compradas, como o prefácio dava a entender, mostrando que Figueiredo Pimentel era, na verdade, por talento ou por escândalo, um autor comentadíssimo na imprensa. No prefácio, o escritor reconhecia que nunca lhe faltara editor. Por isso, Artur não entendia o tom amargo e se perguntava: "que mais quer Figueiredo Pimentel? De que ou de quem se queixa"? Valentim Magalhães aconselhou que o autor rasgasse o prefácio difamador e o retirasse da segunda edição do livro. Artur preferia chamar o romance de "conto desenvolvido", mas notava que, "se não era um livro escrito para senhoras", O terror dos maridos também não era tão escandaloso como os anúncios apregoavam. O livro tinha "páginas bem observadas" e revelava "bom manejo" da língua portuguesa (O País, 26/04/1897, p. 1). Valentim Magalhães ainda identificava algumas incorreções no estilo, mas declarava sua aprovação ao romance, a seu ver superior a Um canalha e Suicida! (A Notícia, 08/04/1897, p. 1). Talvez a homenagem os tivesse amolecido, afinal.

A resenha mais generosa saiu na coluna "Sobre a mesa", no jornal Gazeta de Petrópolis, em junho de 1897. O articulista aponta para a grande ironia do romance e do título, pois o protagonista era um "burro". Elogia a justeza da escandalosa cena final, com a masturbação em público, quando Paulo Gurgel se comporta como "um simples colegial obtuso" e "arde numa autocombustão de gozo":

O tipo fica estatelado com esta chave de ouro para a qual muito concorreu a liga duma prosa cursiva e amena, fluente e adorável, feita ao correr da pena, sem o menor ressalto de byronismo, por meio de períodos curtos, incisivos, anavalhados (Gazeta de Petrópolis, 27/06/1897, p. 1).

$\mathrm{O}$ articulista reconhecia que faltava a $O$ terror dos maridos a observação e acuidade de análise que se viam em outras obras naturalistas, mas isso não diminuía a audácia do livro nem sua "vontade firme" de expor o escândalo e a hipocrisia das classes abastadas. Para aqueles que ainda não haviam admirado "a sem cerimônia de Zola ao abordar os momentos 
psicológicos da vida na espécie", "certos desafogos da linguagem usados no romance" podiam ser espantosos. Mesmo assim, era preciso compreender que essas audácias resultavam do compromisso dos escritores naturalistas com a verdade. Como prova de pureza da alma de Figueiredo Pimentel, o resenhista lembrava sua contribuição à literatura das crianças com a Biblioteca Infantil. Na prosa de ficção, era "um espírito moderno, faceto, difuso, justo e sincero", que não desejava escamotear para as gerações futuras "a engrenagem disto a que chamamos Vida" (Gazeta de Petrópolis, 27/06/1897, p. 1). Vozes como a do articulista da coluna "Sobre a Mesa" eram minoritárias e não representavam a opinião dos escritores dominantes sobre Figueiredo Pimentel.

\section{Considerações finais}

Suicida! foi o romance mais bem recebido de Figueiredo Pimentel (entre os homens de letras) porque era um retrato desiludido da decadência de uma classe recém-desaparecida ou em declínio (os fazendeiros escravistas), e não a burguesia urbana que retratou nos outros romances. A crítica ao sistema monárquico e ao escravismo, assim como a adesão ao ideário republicano, eram marcas salientes de romances naturalistas brasileiros canônicos, como $O$ mulato (1881) e O cortiço (1890), de Aluísio Azevedo; A carne (1888), de Júlio Ribeiro; e A normalista (1893), Bom-Crioulo e Tentação (1896), de Adolfo Caminha. Em Suicida!, a doença, a violência, o sadismo e o crime eram inerentes à lavoura escravista do Brasil imperial, num relato sombrio da decadência da casa-grande brasileira que Lucio Cardoso (1913-1968) retomaria, com fôlego épico, em Crônica da casa assassinada (1959). De muitos modos, o naturalismo brasileiro era o romance da crise do Brasil imperial. Suicida! se encaixava nessa moldura estético-política, cara aos escritores dominantes. Ele também revisitava temas comuns a essa tradição, como a histeria feminina, a hereditariedade, a degradação e a esterilidade.

Tanto Domingos Pacheco quanto Paulo Gurgel possuíam personalidades ambíguas, forjadas em circunstâncias de abandono e solidão, que os fizeram inseguros, fracos de vontade, desconfortáveis na própria pele. Nesse sentido, eram "produtos do meio", outra formulação cara ao naturalismo. Sem precisar forçar a interpretação, podemos dizer que ambos eram sexualmente impotentes. Quem pensaria em escrever um romance sobre homens impotentes? Ou sobre um "burro"? Se houvesse um protótipo do homem naturalista, ele seria Jerônimo, o cavouqueiro incansável de $O$ cortiço, um "touro" que só sossegou quando dormiu

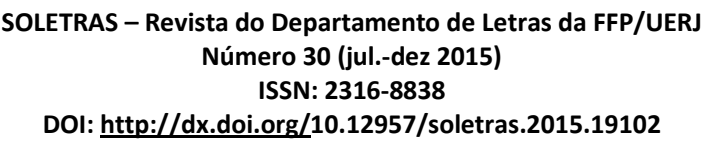


com Rita Baiana. No romance de Aluísio, os moradores da estalagem eram pobres, mas gostavam de estar vivos e tinham confiança no futuro. Domingos Pacheco e Paulo Gurgel, em contraste, adotavam a perspectiva crepuscular do declínio, que podia servir ao Império em Suicida!, mas servia também - o que era menos palatável - ao novo Brasil republicano em $O$ terror dos maridos. Os dois protagonistas eram "heróis mancos" (HAYES, 1971) personagens castrados simbolicamente, portadores de uma ferida física (uma doença) ou moral (uma mania ou fobia), que os paralisava e matava. Embora pouco conhecida pela historiografia, essa literatura desiludida do fim do século XIX também era considerada ficção naturalista (BAGULEY, 1990).

Artur Azevedo gostou de O terror dos maridos, mas preferiu chamá-lo de "conto desenvolvido", como forma de negar ao livro o título mais nobre de "romance". Valentim Magalhães concordou e sugeriu "romancete" ou "novela", que o próprio Figueiredo Pimentel, no prefácio, reconhecia como classificação justa para a obra. De fato, $O$ terror dos maridos (mas também $O$ aborto, Um canalha e Suicida!) era um livro de 150 a 200 páginas, impresso como letras grandes, que se podia "ler em duas horas, de um jato", como cronometrou Valentim Magalhães (A Notícia, 08/04/1897, p. 1). Isso se explicava pelo vínculo do escritor com a literatura de jornal. Os romances naturalistas de Figueiredo Pimentel tinham a ligeireza de obras escritas às pressas, com pouca pesquisa e composição, para sair nos jornais em prazos estipulados, com vistas a atrair e fidelizar leitores. As descrições eram breves, os diálogos ágeis e o ritmo veloz (GENS, 1997). Tanto O aborto quanto Suicida! foram publicados em folhetins na imprensa antes de virar livros. Como eles, Um canalha e $O$ terror dos maridos eram antes crônicas alongadas do que romances, no sentido da tradição da epopeia clássica. Estaria aí outra razão para o esquecimento dos romances naturalistas de Figueiredo Pimentel.

\section{Referências bibliográficas:}

BAGULEY, David. Naturalist fiction. The entropic vision. Cambridge: Cambridge University Press, 1990.

BEZERRA, Carlos Eduardo. Bom-Crioulo: um romance de literatura gay made in Brazil. Bagoas: estudos gays, gêneros e sexualidades. Natal: Universidade Federal do Rio Grande do Norte, vol. 1, n. 1, p. 193-210, jul/dez 2007.

CATHARINA, Pedro Paulo Garcia Ferreira. $O$ aborto, um best-seller naturalista esquecido. In: PIMENTEL, Figueiredo. O aborto. Estabelecimento do texto e organização de Leonardo Mendes e Pedro Paulo Garcia Ferreira Catharina. Rio de Janeiro: 7Letras, 2015, p. 133-151. 
EDMUNDO. Luiz. O Rio de Janeiro do meu tempo. Rio de Janeiro: Imprensa Nacional, 1938.

EL FAR, Alessandra. Páginas de sensação: literatura popular e pornográfica no Rio de Janeiro (1870-1924). São Paulo: Companhia das Letras, 2004.

FOSTER, David William. Adolfo Caminha's Bom-Crioulo: a Founding Text of Brazilian Gay Literature. In: _. Gay and Lesbian Themes in Latin American Fiction. Austin: University of Texas Press, 1991, p. 9-22.

GENS, Rosa Maria de Carvalho. Acadêmicos e esquecidos: ficção brasileira nas primeiras décadas do século. Rio de Janeiro: Universidade Federal do Rio de Janeiro, 1997. Tese de Doutorado em Literatura Brasileira.

GRIECO, Agripino. Evolução da Prosa Brasileira. Rio de Janeiro: Ariel Editora, 1933.

HAYS, Peter. The limping hero: grotesques in literature. New York: New York University Press, 1971.

HOWES, Robert. Raça e sexualidade transgressiva em Bom-Crioulo de Adolfo Caminha. Graphos. Revista de Pós-Graduação em Letras. João Pessoa: Universidade Federal da Paraíba, vol. 7, n. 2/1, p. 171-190, 2005.

KENDRICK, Walter. The secret museum: pornography in modern culture. New York: Viking, 1987.

LAMONICA, Lucas de Castro. Filomena Borges: romance, imprensa e política. Campinas, SP: Universidade Estadual de Campinas, 2015. Dissertação de Mestrado em Teoria e História Literária.

LEÃO, Andréa Borges. Brasil em imaginação: livros, impressos e leituras infantis (1890 1915). Fortaleza: INESP/UFC, 2012.

MAGALHÃES, Valentim. O irresistível. In: Vinte contos. Rio de Janeiro: Laemmert, 1895, p. $39-50$.

MENDES, Leonardo; VIEIRA, Renata Ferreira. Naturalismo e banalidade em Um canalha, de Figueiredo Pimentel. Navegações. Porto Alegre: PUC-RS, v. 7, n. 2, p. 116-124, jul/dez 2014.

MENDES, Leonardo. O Zola da Praia Grande: Figueiredo Pimentel e o naturalismo. In: PIMENTEL, Figueiredo. O aborto. Estabelecimento do texto e organização de Leonardo Mendes e Pedro Paulo Garcia Ferreira Catharina. Rio de Janeiro: 7Letras, 2015, p. 7-14.

MEYER, Marlyse. Folhetim: uma história. São Paulo: Companhia das Letras, 1996.

NEEDEL, Jeffrey. A Tropical Belle Époque. Elite Culture and Society in Turn-of-century Rio de Janeiro. Cambridge: Cambridge UP, 1987.

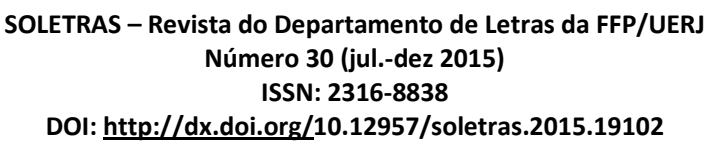


PICK, Daniel. Faces of degeneration: a European disorder, 1848-1918. Cambridge: Cambridge University Press, 1989.

PIMENTEL, Figueiredo. O aborto. Rio de Janeiro: 7Letras, 2015 [1893].

. Suicida! Rio de Janeiro: Fauchon \& C., 1895.

O terror dos maridos. Rio de Janeiro: Cruz Coutinho, 1896.

VIEIRA, Renata Ferreira. Uma penca de canalhas: Figueiredo Pimentel e o naturalismo no Brasil. Rio de Janeiro: Universidade do Estado do Rio de Janeiro, 2015. Dissertação de Mestrado em Teoria Literária.

\title{
Jornais e revistas consultados:
}

Almanaque Literário e Estatístico do Rio Grande do Sul (RS), A Notícia (RJ), A Semana (RJ), O País (RJ), Diário de Notícias (RJ), Cidade do Rio (RJ), Jornal do Brasil (RJ), Gazeta de Notícias (RJ), Revista Ilustrada (RJ), Revista do Brasil (RJ), A Cigarra (RJ), Gazeta de Petrópolis (RJ), Correio Paulistano (SP), A Nação (SP), O Cachoeirano (ES), A República (PR), República (SC), Pacotilha (MA), Correio de Minas (MG).

\section{The trajectories of Suicida! (1895) and $O$ terror dos maridos (1896), forgotten naturalist novels by Figueiredo Pimentel}

\begin{abstract}
This work studies the publication, circulation and reception of forgotten naturalist novels Suicida! (1895) and $O$ terror dos maridos (1896), by Alberto Figueiredo Pimentel (1869-1914), a Brazilian writer who had an outstanding performance in the literary and journalistic scene in Rio de Janeiro in the decades from 1890 to 1910. Like other intellectuals of the First Republic, Figueiredo Pimentel was a polygraph who practiced various genres of writing: poetry, short story, novel, drama, chronic, serial, and notably children's literature, of which he was a successful pioneer in Brazil. His debut novel $O$ aborto (1893) was a scandalous best seller at the time. In order to tell the selected novels' history, we will use the Periodicals available at the Brazilian Digital Newspaper Library/FBN.
\end{abstract}

Keywords: Figueiredo Pimentel. Naturalism. Literature. Journalism.

Recebido em: 07 de outubro de 2015.

Aprovado em: 22 de novembro de 2015 .

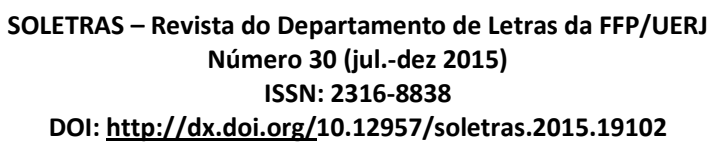

